\title{
Peripheral mononuclear leucocyte $\beta$ adrenoceptors and non-specific bronchial responsiveness to methacholine in young and elderly normal subjects and asthmatic patients
}

\author{
Martin J Connolly,* Joseph J Crowley, Christopher P Nielson, Nirmal B Charan, \\ Robert E Vestal
}

\section{Clinical}

Pharmacology and Gerontology Research Unit

M J Connolly

C P Nielson

E Vestal

Pulmonary Medicine Section

J J Crowley

N B Charan

Department of Veterans Affairs Medical Center, 500 W. Fort Street, Boise Idaho 83702, USA

and

Departments of Medicine and Pharmacology, University of Washington School of Medicine, Seattle, Washington 98195 , USA

Reprint requests to: DrR E Vestal.

* Present position: Senior Lecturer in Care of the Elderly and Medicine, University of Manchester Barnes Hospital, Cheadle, Cheshire SK8 2NY, UK

Received 8 February 1993 Returned to authors 12 May 1993

Revised version received

9 August 1993

Accepted for publication

Accepted for put

\section{Abstract}

Background - As $\beta$ adrenoceptor dysfunction occurs in both the normal elderly subject and in young asthmatic patients, the hypothesis was examined that age related $\beta$ adrenoceptor changes are important in the pathogenesis of late onset asthma in old age.

Methods - Subjects were non-smokers who comprised 17 young normal subjects of mean (SE) age $29.4(1.3)$ years, 17 elderly normal subjects of $67 \cdot 2(1 \cdot 3)$ years, seven young asthmatic patients of $31.0(2 \cdot 8)$ years, and 17 elderly asthmatic patients of $68.5(1.4)$ years. All asthmatic patients withheld inhalers for 12 hours and oral treatment for 24 hours before each study day. Subjects underwent an inhaled methacholine challenge (Newcastle dosimeter method) on two nonconsecutive days. The slope of the flow at $50 \%$ of the vital capacity $\left(\mathrm{FEF}_{50}\right)$ doseresponse curve was derived from the percentage fall in FEF $_{50}$ divided by methacholine dose $\left(\mathrm{sFEF}_{50}\right)$. Beta-adrenoceptor density (Bmax) and affinity (\%KH) were determined with ( $\left.{ }^{125} \mathrm{I}\right)$ iodocyanopindolol as the radioligand in membranes prepared from mononuclear leucocytes.

Results - Log sFEF s0 $_{50}$ was shown to be reproducible (repeatability coefficient 0.41 ) on the two study days and was inversely related to \% KH but not to $\mathrm{Bmax}$. Multiple regression analysis (all 58 subjects, overall $R^{2}=0.57$ ) revealed an inverse relation between $\log \mathrm{sFEF}_{50}$ and $\% \mathrm{KH}$, and between $\log \mathrm{sFEF}$ and $\mathrm{Bmax}$. The inverse relation between $\log \mathbf{s F E F}_{50}$ and $\% K_{H}$ was preserved whereas that between $\log$ SFEF $_{50}$ and $B$ max was lost when young asthmatic subjects or when all asthmatic subjects were excluded from multiple regression analysis.

Conclusions - The $\beta$ adrenoceptor dysfunction observed in late onset asthma may be similar to that seen during ageing. Thus late onset asthma may represent the extreme of a spectrum of age associated $\beta$ adrenoceptor dysfunction.

(Thorax 1994;49:26-32)

In elderly patients asthma has a prevalence of at least $6.5 \%$ and is often unrecognised. ${ }^{12}$
Although most elderly asthmatic patients first develop asthma in adulthood, ${ }^{1}$. the pathogenesis of late onset asthma is poorly understood. Reduced $\beta$ adrenoceptor responsiveness is seen in young asthmatic patients ${ }^{3-8}$ and in normal elderly subjects. ${ }^{9-13}$ Increased non-specific bronchial responsiveness, determined by methacholine or histamine challenge, is characteristic of asthma, its degree correlating with the severity of the asthma. ${ }^{14-16}$ Beta-receptor dysfunction has long been postulated as a cause of increased non-specific bronchial responsiveness and of asthma itself. ${ }^{17}$ This should imply an increasing prevalence of high levels of non-specific bronchial responsiveness with increasing age, and a relation between the degree of $\beta$ adrenoceptor function and the level of non-specific bronchial responsiveness. However, evidence of the former is confusing, ${ }^{18-27}$ and the latter hypothesis has been little investigated..$^{27} 28$

We have examined the hypothesis that age related $\beta$ adrenoceptor dysfunction occurs in late onset asthma by assessing: (1) mononuclear leucocyte membrane $\beta$ adrenoceptor density and affinity in elderly, late onset asthmatic and elderly non-asthmatic subjects, and in young asthmatic and non-asthmatic subjects; and (2) the relation between non-specific bronchial responsiveness to methacholine and the above in vitro indices of $\beta$ adrenoceptor function in all four subject groups.

\section{Methods}

SUBJECTS

Healthy young (18-50 years) and elderly (6085 years) non-asthmatic subjects, and young (22-42 years) and elderly (60-85 years) asthmatic subjects who were otherwise healthy were recruited from the community. Sixteen of the healthy young subjects had participated in a previous study using an identical proto$\mathrm{Col}^{29}$ and their data are included for comparison with the other groups. In addition, data on the sensitivity of the neutrophil respiratory burst to inhibition by isoproterenol in many of the subjects have been reported previously. ${ }^{30}$ Table 1 gives subject characteristics for each group. Asthmatic subjects were those with variable respiratory symptoms and documented $20 \%$ variability in forced expiratory volume in one second $\left(\mathrm{FEV}_{1}\right)$, either spontaneously or following a single dose of inhaled $\beta$ agonist. Non-asthmatic (normal) subjects had 
Table 1 Mean (SE) characteristics of study subjects

\begin{tabular}{|c|c|c|c|c|}
\hline $\begin{array}{l}\text { Subject } \\
\text { group }\end{array}$ & $\stackrel{n}{(M: F)}$ & $\begin{array}{l}\text { Age } \\
\text { (years) }\end{array}$ & $\begin{array}{l}\text { Duration of } \\
\text { asthma (years) }\end{array}$ & $\begin{array}{l}\text { Baseline FEV } \\
\text { (\% predicted })^{*}\end{array}$ \\
\hline Young normal & $\begin{array}{l}17 \\
(8: 9)\end{array}$ & $29 \cdot 4(1 \cdot 3)$ & - & $105.9(2.6)$ \\
\hline Young asthmatic & $\begin{array}{c}7 \\
(3: 4)\end{array}$ & $31 \cdot 0(2 \cdot 8)$ & $11.9(5 \cdot 1)$ & $100 \cdot 8(3 \cdot 7)$ \\
\hline Elderly normal & $\begin{array}{c}17 \\
(11: 6)\end{array}$ & $67 \cdot 2(1 \cdot 3)$ & - & $109 \cdot 1(3 \cdot 4)$ \\
\hline Elderly asthmatic & $\begin{array}{l}17 \\
(11: 6)\end{array}$ & $68.5(1.4)$ & $18.8(5.4)$ & $80.9(3.0)$ \\
\hline
\end{tabular}

* Determined according to standards published by Morris. ${ }^{58}$

no respiratory or atopic history and normal baseline lung function. Exclusion criteria for all groups included: cognitive impairment; pregnancy; cardiac disease; thyroid disorder; current cigarette smoking or smoking history of $>10$ pack years; respiratory infection, severe wheeze, medication change, or antihistamine treatment within six weeks; past or present treatment with $\beta$ adrenergic antagonists, calcium antagonists or angiotensin converting enzyme (ACE) inhibitors; baseline $\mathrm{FEV}_{1}$ (each study day) less than $60 \%$ of predicted.

Volunteers were screened by history, physical examination, and electrocardiography. A pregnancy test was performed where appropriate. Subjects refrained from drinks containing caffeine and oral medication for 24 hours and from inhalers for at least 12 hours before each study period ( 48 hours for long acting medication).

Of the 17 elderly asthmatic patients four were receiving no drugs and 13 were taking anti-asthma medication (some on multiple medication). Four subjects used occasional inhaled $\beta$ agonists only (less than once daily), nine used regular inhaled $\beta$ agonists, seven used methylxanthines, four inhaled steroids, and five received inhaled cromoglycate. Of the seven young asthmatic patients six used inhaled $\beta$ agonists regularly and two regularly inhaled steroids.

\section{STUDY PROTOCOL}

Subjects were studied on non-consecutive days within a seven day period according to a protocol detailed elsewhere. ${ }^{29}$ Briefly, the protocol comprised the following:

Day 1: Subjects rested semirecumbent for 30 minutes, following which they sat up and inhaled methacholine was administered (initial dose $1.5 \mu \mathrm{g}$ methacholine chloride) by a modified Newcastle dosimeter method. ${ }^{31}$ A single measurement of maximal expiratory flow at $50 \%$ of vital capacity $\left(\mathrm{FEF}_{50}\right)$ was obtained immediately before each dose. Alternative end points were $35 \%$ fall in $\mathrm{FEF}_{50}$ or administration of the maximum cumulative dose of $6.4 \mathrm{mg}$ methacholine. $\mathrm{FEF}_{50}$ was monitored until it returned to normal. A bronchodilator was not given. The output of 12 Acorn "System 22" Turbo Nebulisers (Medic-Aid Ltd, Bognor Regis, West Sussex, UK) was maintained at $10 \mu \mathrm{l}$ per nebulisation (standard deviation $0.9-2.5 \%$ ) by computer controlled variation of nebulisation time.

Day 2: The protocol was identical to that for
Day 1 except that a blood sample was obtained immediately before methacholine challenge.

Plasma was separated and frozen $\left(-70^{\circ} \mathrm{C}\right)$ for catecholamine and IgE assays and mononuclear leucocytes were harvested from whole blood for assay of mononuclear leucocyte $\beta$ adrenoceptor characteristics.

All subjects gave written informed consent to participate in the study which was approved by the Human Subjects Committee of the University of Washington and the Research and Development Committee of the Boise Department of Veterans Affairs Medical Center.

\section{ASSAY METHODS}

The assay methods are described in detail elsewhere. ${ }^{29}$ Plasma catecholamine concentrations were measured by the radioenzymatic method of Peuler and Johnson, ${ }^{32}$ and plasma IgE was determined by an amplified immunoradiometric assay. Mononuclear cells were isolated by density gradient centrifugation with Ficoll-Hypaque at $4^{\circ} \mathrm{C}, 33$ counted, and then lysed. ${ }^{29}$ Prepared membranes were stored dry at $-70^{\circ} \mathrm{C}$. The Bradford method was used for protein analysis. ${ }^{34}$ Beta-adrenoceptor density and affinity in mononuclear leucocyte membranes were determined with $\left({ }^{125} \mathrm{I}\right)$ iodocyanopindolol (ICYP, $2200 \mathrm{Ci} / \mathrm{mmol}$, NEN Research Products, Boston, Massachusetts, USA), as previously described. ${ }^{29}$ Receptor density (Bmax) and affinity for antagonist (KD) were determined from saturation isotherms by computer analysis using Lundon I (Lundon Software Inc, Cleveland, Ohio, USA). ${ }^{35}$ Agonist competition curves were analysed with a two site model and InPlot (GraphPad Software, San Diego, California, USA), which employs the Marquardt algorithm for non-linear regression. ${ }^{36}$

\section{STATISTICAL ANALYSIS}

The following information was derived for each subject: (1) simplified slope ${ }^{37}$ of $\mathrm{FEF}_{50}$ $\left(\mathrm{sFEF}_{50}\right)$ dose-response curve to methacholine (in duplicate). This is a measure of nonspecific bronchial responsiveness with units expressed as the percentage fall in $\mathrm{FEF}_{50} / \mathrm{mg}$ methacholine. In this analysis slope is positively related to non-specific bronchial responsiveness; (2) total number of $\beta$ adrenoceptors/mg cell membrane protein (Bmax); (3) dissociation constants for isotope and isoproterenol; and (4) percentage of receptors in high affinity state $\left(\% \mathrm{~K}_{\mathrm{H}}\right)$.

The following analyses were performed: (1) reproducibility of $\mathrm{sFEF}_{50}$ by the method of Bland and Altman; ${ }^{38}$ (2) Student's unpaired $t$ tests comparing IgE and catecholamine levels between groups; (3) one way analysis of variance (ANOVA) to compare in vitro results between groups, allowing for sex differences; and (4) linear and multiple regression analysis employing $\mathrm{sFEF}_{50}$ as the dependent variable. Unless otherwise stated, results are expressed as mean (SE). Statistical significance was defined at the $5 \%$ level. 


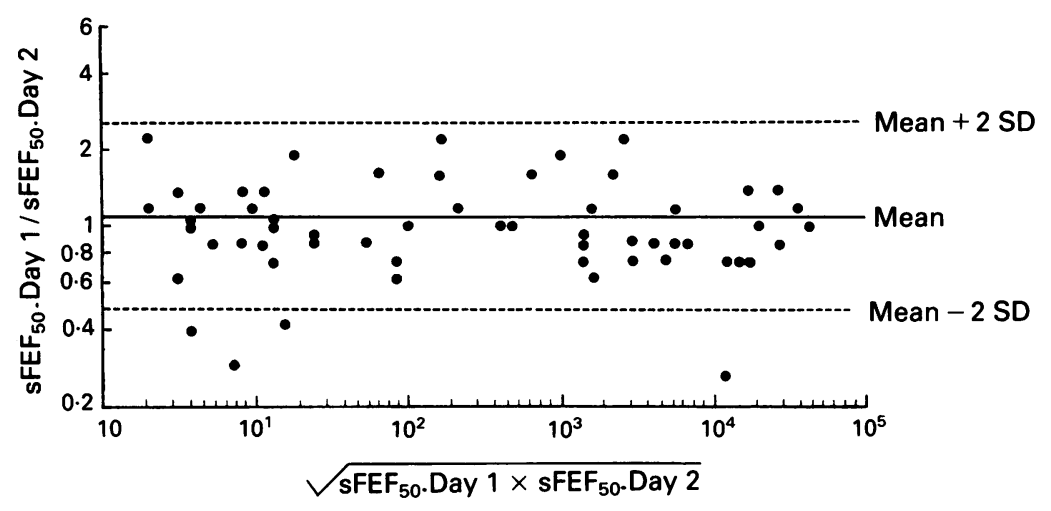

Figure 1 Repeatability of $\log s E F_{50}$ to methacholine (Day 1 v Day 2). Repeatability is expressed as the ratio of the slope on Day 1 to that on Day 2 and plotted against the geometric mean of the pair. The ratios did not differ significantly from unity. The solid horizontal line indicates the overall geometric mean and the broken horizontal lines represent the geometric mean plus or minus two standard deviations which constitute the $95 \%$ limits for repeat $s F E F_{50}$ determination.

\section{Results}

RESPONSE TO METHACHOLINE

Elderly asthmatic subjects had a lower baseline $\mathrm{FEV}_{1}$ (\% predicted) than young normal subjects $(p<0.0001)$, elderly normal subjects $(\mathrm{p}<0.0001)$, and young asthmatic subjects $(p<0.001)$. To evaluate reproducibility of the response to methacholine, for each subject the ratio of the simplified slope of $\mathrm{FEF}_{50}$. Day 1 $\left(\mathrm{sFEF}_{50}\right.$.Day 1) to $\mathrm{sFEF}_{50}$.Day 2 on a log scale (equivalent to difference of the logs on a linear scale) was plotted against the geometric mean of the pair on a log scale (equivalent to mean $\log \mathrm{sFEF}_{50}$ on a linear scale). The ratios did not differ significantly from unity (fig 1). The geometric means of $\mathrm{sFEF}_{50}$ on Days 1 and 2 were $237.8 \%$ fall $/ \mathrm{mg}$ ( $95 \%$ confidence limits for mean 113.3 to $499.5 \%$ fall $/ \mathrm{mg}$ ) and $211.1 \%$ fall $/ \mathrm{mg}$ ( $95 \%$ confidence limits for mean $100 \cdot 6$ to $442 \cdot 8 \%$ fall $/ \mathrm{mg}$ ), respectively. The geometric mean of the ratios of $\mathrm{sFEF}_{50}$. Day 1 to $\mathrm{sFEF}_{50}$. Day 2 was $1 \cdot 110$ (95\% confidence limits for mean 0.982 to 1.254$)$. Coefficient of repeatability ${ }^{38}$ was 0.408 . Thus, the $95 \%$ confidence limits for repeat $\mathrm{sFEF}_{50}$ determination were $0.39 \times$ initial $\mathrm{sFEF}_{50}$ to $2.56 \times$ initial sFEF $_{50}$

The geometric mean of $\mathrm{sFEF}_{50}$. Day 2 was $6.47 \%$ fall $/ \mathrm{mg}$ ( $95 \%$ limits for mean 4.65 to

Table 2 Mean (SE) plasma levels of IgE and catecholamines

\begin{tabular}{lcll}
\hline Subject group & IgE (units/ml) & Adrenaline $($ pmol/l) & Noradrenaline (nmol/l) \\
\hline Young normal & $43.2(16 \cdot 5)$ & $217(37)$ & $1.82(0 \cdot 12)$ \\
Young asthmatic & $212.6(140 \cdot 2)$ & $191(56)$ & $1.97(0 \cdot 37)$ \\
Elderly normal & $53.1(17 \cdot 4)$ & $220(31)$ & $2 \cdot 22(0 \cdot 23)$ \\
Elderly asthmatic & $100 \cdot 0(38 \cdot 7)$ & $258(79)$ & $2 \cdot 85(0.32)$ \\
\hline
\end{tabular}

Table 3 Characteristics of $\beta$ adrenoceptors in membranes of peripheral mononuclear leucocytes

\begin{tabular}{|c|c|c|c|c|}
\hline Subject group & $B \max (\mathrm{fmol} / \mathrm{mg}$ ) & $\% K_{H}$ & $K D_{H}(\mathrm{nmol} / \mathrm{l})$ & $K D L(\mu m o l / l)$ \\
\hline Young normal & $45.57(6.25)$ & $60 \cdot 68(3 \cdot 76)$ & \multirow{4}{*}{$\begin{array}{l}218 \\
(138-344) \\
134 \\
(58-308) \\
95 \\
(47-192) \\
38 \\
(17-85)\end{array}$} & \multirow{4}{*}{$\begin{array}{l}4 \cdot 79 \\
(2 \cdot 68-8 \cdot 55) \\
3 \cdot 98 \\
(1 \cdot 23-12 \cdot 92) \\
2 \cdot 27 \\
(1 \cdot 31-3 \cdot 95) \\
1 \cdot 84 \\
(1 \cdot 14-2 \cdot 96)\end{array}$} \\
\hline Young asthmatic & $26.63(4.77)$ & $49.21(9.54)$ & & \\
\hline Elderly normal & $33.84(4 \cdot 31)$ & $45 \cdot 26(5 \cdot 83)$ & & \\
\hline Elderly asthmatic & $43.26(5.65)$ & $31 \cdot 13(4 \cdot 30)$ & & \\
\hline
\end{tabular}

Data are mean (SE) except for KDH and KDL which are geometric means and for which the $95 \%$ confidence limits are shown in parentheses.
$9.00 \%$ fall $/ \mathrm{mg}$ ) in young normal subjects, $115.6 \%$ fall $/ \mathrm{mg}$ (95\% limits 43.3 to $308.6 \%$ fall $/ \mathrm{mg} ; \mathrm{p}<0.0001 v$ young normal subjects) in elderly normal subjects, $844.9 \%$ fall $/ \mathrm{mg}(95 \%$ limits 123.6 to $577.6 \%$ fall $/ \mathrm{mg}$; $<<0.0001 v$ young normal subjects) in young asthmatic patients, and $8030 \%$ fall $/ \mathrm{mg}(95 \%$ limits 4638 to $13903 \%$ fall $/ \mathrm{mg} ; \mathrm{p}<0.0001 v$ elderly normal subjects) in elderly asthmatic patients. The range of $\mathrm{sFEF}_{50}$. Day 2 was 1.72 to $23.5 \%$ fall $/ \mathrm{mg}$ in young normal subjects, 1.15 to $2020 \%$ fall $/ \mathrm{mg}$ in elderly normal subjects, 23.0 to $19329 \%$ fall $/ \mathrm{mg}$ in young asthmatic patients, and 1380 to $46272 \%$ fall $/ \mathrm{mg}$ in elderly asthmatic patients.

\section{IGE AND PLASMA CATECHOLAMINES}

As shown in table 2, elderly asthmatic patients had higher resting noradrenaline levels than young normal subjects $(p<0.005)$. ANOVA (sex and subject group as categorising variables) confirmed the difference in noradrenaline levels among all four groups $\left(F_{1,56}=4 \cdot 21\right.$, $\mathrm{p}<0.01$ ), and between elderly asthmatic and young normal subjects $\left(F_{1,32}=7 \cdot 76, p<0.01\right)$, with similar trends between other groups except young normal $v$ young asthmatic subjects, and elderly normal $v$ young asthmatic subjects. Plasma levels of IgE and adrenaline did not differ significantly between groups.

\section{CHARACTERISTICS OF $\beta$ ADRENOCEPTORS}

Since absolute values for dissociation constants of high (KDH) and low affinity (KDL) receptors for isoproterenol were not normally distributed, these values were logarithmically transformed before analysis to ensure a normal distribution. As shown in table 3, for all four subject groups there was a significant intergroup difference in $\% \mathrm{KH}_{\mathrm{H}}\left(\mathrm{F}_{1,56}=6.07\right.$, $\mathrm{p}=0.001$ ), and in the dissociation constant $(\mathrm{KDH})$ of the high affinity site $\left(\mathrm{F}_{1,56}=5 \cdot 18\right.$, $\mathrm{p}<0.005$ ), but no difference in Bmax or in the dissociation constant (KDL) of the low affinity site. Young normal subjects had significantly higher $\% \mathrm{~K}_{\mathrm{H}}$ values $\left(\mathrm{F}_{1,32}=5 \cdot 10, \mathrm{p}<0.05\right)$ and $\mathrm{KDH}$ values $\left(\mathrm{F}_{1,32}=5.02, \mathrm{p}<0.05\right)$ than elderly normal subjects. Other variables were not significant. Although there was a trend towards a higher $\% \mathrm{KH}$ in elderly normal subjects than in elderly asthmatic patients, the difference did not reach statistical significance. ANOVA comparing young normal with elderly asthmatic subjects showed differences for $\% \mathrm{KH}_{\mathrm{H}}$ $\left(\mathrm{F}_{1,32}=25.9, \mathrm{p}<0.0001\right), \mathrm{KDL} \quad\left(\mathrm{F}_{1,32}=8.62\right.$, $\mathrm{p}<0.01)$, and $\mathrm{KDH}\left(\mathrm{F}_{1,32}=15.46, \mathrm{p}<0.0005\right)$, but not for Bmax. Young asthmatic subjects had lower Bmax values than young normal subjects $\left(F_{1,22}=7.06, p<0.02\right)$ or elderly asthmatic patients $\left(F_{1,22}=4.23, p<0.05\right)$. Young asthmatic patients had higher $\% \mathrm{KH}_{\mathrm{H}}$ values than elderly asthmatic patients $\left(F_{1,22}=5 \cdot 67\right.$, $\mathrm{p}<0.05)$. KDH and $\mathrm{KDL}$ values did not differ between young asthmatic subjects and other groups. ANOVA revealed no sex differences in any analysis.

Although there was no relation between log sFEF $_{50}$ and $\mathrm{Bmax}, \log \mathrm{sFEF}_{50}$ was inversely 


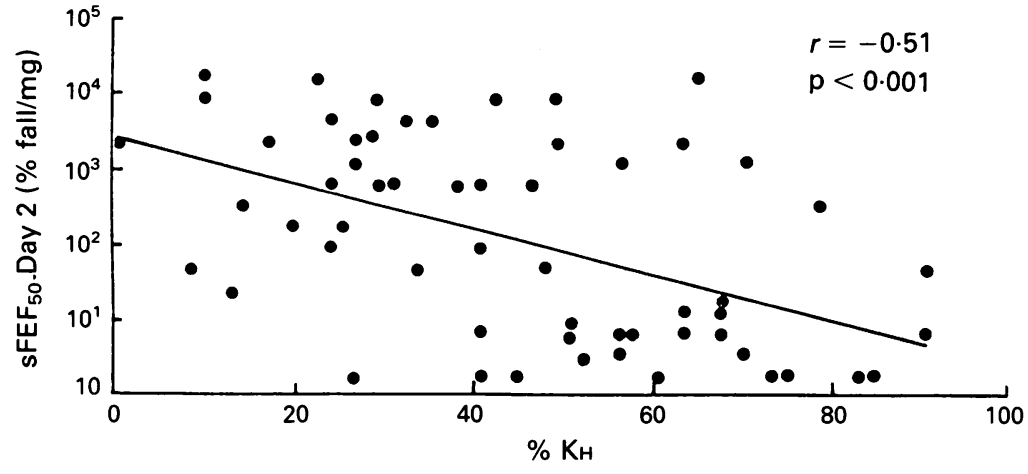

Figure 2 Linear regression analysis of bronchial responsiveness ( $s F E F_{50}$. Day 2 ) $v$ the percentage of $\beta$ adrenoceptors in the high affinity state $(\% \mathrm{KH})$.

related to $\% \mathrm{KH}$ (fig 2 ). To evaluate further the relative importance of factors that might be expected to influence the response to methacholine, multiple regression analysis was performed with $\log \mathrm{sFEF}_{50}$ as the dependent variable (table 4). Data from all 58 subjects were used for these analyses. Log $\mathrm{sFEF}_{50}$ showed a significant inverse relation with both $\% \mathrm{KH}$ $(\mathrm{p}<0.05)$ and $B \max (\mathrm{p}<0.05)$, with a high coefficient of multiple regression.

When multiple regression analysis was repeated in normal subjects only (table 5), the inverse relationship between $\log \mathrm{sFEF}_{50}$ and $\% \mathrm{~K}_{\mathrm{H}}$ was preserved $(\mathrm{p}<0.05)$, but that between log $\mathrm{sFEF}_{50}$ and Bmax was lost. Similar results were obtained with multiple regression in young and elderly normal subjects and elderly asthmatic subjects (that is, excluding young asthmatic subjects, table 6 ).

Table 4 Multiple regression analysis of non-specific bronchial responsiveness (log $s F E F_{s 0}$. Day 2) against $\beta$ adrenoceptor parameters, catecholamines, and IgE in all 58 subjects

\begin{tabular}{lllll}
\hline & $b$ & $S E$ & $t$ & $p$ \\
\hline Intercept & 6.35 & 1.00 & 6.35 & $<0.0001$ \\
\% KH & -0.013 & 0.006 & -2.17 & $<0.05$ \\
Baseline FEV $_{1}(\%)$ & -0.041 & 0.008 & -5.28 & $<0.0001$ \\
Age & 0.022 & 0.007 & 3.16 & $<0.05$ \\
Bmax & -1.125 & 0.056 & -2.02 & $<0.05$ \\
\hline
\end{tabular}

$\mathrm{b}=$ partial regression coefficient; $\mathrm{SE}=$ standard error; $\mathrm{t}=$ Student's $t$ test; coefficient of multiple regression $\left(R^{2}\right)$ adjusted for degrees of freedom $=0.57$

$\mathrm{KDH}, \mathrm{KDL}$, catecholamines, and IgE were not significant.

Table 5 Multiple regression analysis of non-specific bronchial responsiveness (log $s F E F_{50}$. Day 2) against $\beta$ adrenoceptor parameters, catecholamines, and IgE in young and elderly normal subjects only

\begin{tabular}{lllll}
\hline & $b$ & $S E$ & $t$ & $p$ \\
\hline Intercept & 0.617 & 0.486 & 1.270 & $>0.2$ \\
$\%$ KH & -0.012 & 0.006 & -2.16 & $<0.05$ \\
Age & 0.030 & 0.006 & 4.89 & $<0.0001$ \\
IgE & 0.0018 & 0.0009 & 2.09 & $<0.05$ \\
\hline
\end{tabular}

$\mathrm{b}=$ partial regression coefficient; $\mathrm{SE}=$ standard error; $\mathrm{t}=$ Student's $t$ test; coefficient of multiple regression $\left(R^{2}\right)$ adjusted for degrees of freedom $=0.56$.

$\mathrm{Bmax}, \mathrm{KDH}, \mathrm{KDL}$, catecholamines, and \% baseline $\mathrm{FEV}_{1}$ were not significant.

Table 6 Multiple regression analysis of non-specific bronchial responsiveness (log $s F E F_{s 0}$. Day 2) against $\beta$ adrenoceptor parameters, catecholamines, and IgE (excluding young asthmatic subjects)

\begin{tabular}{lllll}
\hline & $b$ & $S E$ & $t$ & $p$ \\
\hline Intercept & 3.76 & 0.98 & 3.85 & $<0.001$ \\
\% KH & -0.013 & 0.006 & -2.34 & 0.02 \\
Baseline FEV $_{1}(\%)$ & -0.032 & 0.007 & -4.72 & $<0.001$ \\
Age & -0.033 & 0.007 & -5.06 & $<0.001$ \\
\hline
\end{tabular}

$\mathrm{b}=$ partial regression coefficient; $\mathrm{SE}=$ standard error; $\mathrm{t}=$ Student's $t$ test; coefficient of multiple regression $\left(R^{2}\right)$ adjusted for degrees of freedom $=0 \cdot 74$

$\mathrm{Bmax}, \mathrm{KDH}, \mathrm{KDL}$, catecholamines, and IgE were not significant.
Since ANOVA comparing elderly normal and elderly asthmatic subjects had only demonstrated a trend towards an intergroup difference in $\% \mathrm{KH}$, a further multiple regression analysis was performed for these 34 subjects only. It showed significant relations between $\log \mathrm{sFEF}_{50}$ and baseline $\mathrm{FEV}_{1}$ $(\mathrm{p}<0.0005)$ and $\% \mathrm{~K}_{\mathrm{H}}(\mathrm{p}<0.05)$, but not between $\log \mathrm{sFEF}_{50}$ and $\mathrm{Bmax}$.

No overall relation was shown between any in vitro variable and baseline lung function. For young or elderly asthmatic patients there was no relation between any in vitro variable and either duration of asthma or age of onset or between $\log \mathrm{sFEF}_{50}$ and asthma duration or age of onset.

\section{Discussion}

This study has confirmed the reduction in mononuclear leucocyte membrane $\beta$ adrenoceptor affinity with preservation of receptor density in normal elderly men and women. More importantly it has shown that, in comparison with young and elderly normal subjects, mononuclear leucocytes from elderly, late onset asthmatic patients have further reductions in affinity without a reduction in receptor density. Indeed, there was an inverse correlation between non-specific bronchial responsiveness (a marker of asthma severity) and receptor affinity, but not between non-specific bronchial responsiveness and receptor density. These abnormalities in receptor affinity were not seen in young asthmatic patients, although in this latter group the previously described reductions in receptor density compared with young normal subjects were confirmed. Young asthmatic patients were also found to have lower receptor density than elderly asthmatic patients.

Multiple regression analysis employing an index of bronchial responsiveness as the dependent variable showed an inverse relation between responsiveness and both receptor affinity and receptor density when all subjects were included in the analysis. When young asthmatic subjects were excluded, however, the relation between responsiveness and density was lost but the inverse relation between responsiveness and affinity was preserved. This was also true if only normal subjects were included in the analysis, strongly suggesting that the relation is a function of age (or ageing) rather than of asthma.

Taken together these results suggest that the mechanism or mechanisms responsible for $\beta$ adrenoceptor dysfunction in late onset asthma are similar to those underlying age-associated $\beta$ adrenoceptor dysfunction, and distinct from those associated with juvenile onset asthma. If true, then late onset asthma may represent the far end of a spectrum of age-associated $\beta$ adrenoceptor dysfunction.

Although there is controversy as to the adequacy of the mononuclear leucocyte model in terms of the degree to which it reflects changes in airway $\beta$ adrenoceptors, in vitro and in vivo abnormalities of $\beta$ adrenoceptor function are well recognised in young asthmatics ${ }^{3-8}$ and 
have been suggested as a cause of asthma. ${ }^{17}$ Similar in vitro and in vivo abnormalities have been described in normal elderly subjects ${ }^{9-13}$ and may be a consequence of the effects of ageing on the $\beta$ adrenergic receptor adenylyl cyclase system. Nevertheless, the limitations of the mononuclear leucocyte model must be acknowledged.

Lymphocytes and lung membranes of young asthmatic subjects have reduced numbers (density) of $\beta$ adrenoceptors. ${ }^{568}$ In contrast, normal elderly subjects have normal lymphocyte membrane receptor density ${ }^{139-41}$ but reduced receptor affinity for agonist. ${ }^{13}$ This is thought to represent functional uncoupling of the receptor from the adenylyl cyclase complex, and is associated with impaired receptormediated adenylyl cyclase activity. ${ }^{4243}$ Impaired adenylyl cyclase activity is common to asthma and normal ageing. ${ }^{4-1244}$ The possibility that late onset asthma represents the extreme end of a spectrum of ageing effects on the $\beta$ adrenoceptor pathway has not previously been examined, and in vitro studies on $\beta$ receptors of elderly asthmatic subjects have not been reported.

It has been suggested that $\beta$ adrenoceptor dysfunction in ageing is due to downregulation by endogenous catecholamines. ${ }^{113}$ The higher resting noradrenaline levels in the elderly normal and elderly asthmatic subjects in this study are in general agreement with previous literature. ${ }^{111345}$ Our failure to show a relation between noradrenaline levels and either receptor affinity or non-specific bronchial responsiveness level argues against the downregulation hypothesis.

The present finding of a greater degree of bronchial responsiveness in elderly normal than in young normal subjects is entirely consistent with the hypothesis of an association between late onset asthma (and therefore hyperresponsiveness) and age-associated $\beta$ adrenoceptor dysfunction. There is, however, disagreement in the literature as to the effect of age on non-specific bronchial responsiveness. Some studies have indeed suggested a higher level of responsiveness in the elderly ${ }^{19-22}$ while others have found no effect of age. ${ }^{1823-36}$ In some of these latter cases, however, few or no subjects over 65 years were studied..$^{18233}$ Others ${ }^{24}{ }^{26}$ examined the percentage of subjects with hyperresponsiveness (as opposed to absolute level of responsiveness) and at least one ${ }^{24}$ showed a trend towards hyperresponsiveness at the extreme end of the age range. A recent paper which again failed to show an ageassociated increase in airway reactivity included only two of 85 subjects over 70 years. ${ }^{27}$ The young normal subjects in this same study displayed a surprisingly large range of nonspecific bronchial responsiveness, measured as $\mathrm{FEV}_{1}$ slope (over 400 fold, as opposed to 14 fold in the present study), and yet repeatability of their non-specific bronchial responsiveness measurement was not assessed. Two recent large studies ${ }^{4647}$ report conflicting data on the effects of age on bronchial responsiveness in non-smokers.

There are three potential pitfalls with the novel hypothesis of the model of late onset asthma as an age-associated receptor-mediated disease. Firstly, we were unable to study large numbers of drug naive elderly asthmatic subjects. Thus, chronic treatment with inhaled $\beta$ agonists may be implicated in downregulation of $\beta$ adrenoceptors. While this may partially explain our results, it would not explain why the receptor abnormality shown was exclusively one of reduced affinity, whereas similar studies on treated young asthmatics have shown reduced receptor density..$^{5-8}$ Furthermore, it has been shown in older patients with chronic obstructive pulmonary disease that treatment with $\beta$ agonists leads to a fall in density but not in agonist affinity in mononuclear leucocytes. ${ }^{48}$

Secondly, the methacholine challenge itself (Day 1) may have affected in vitro $\beta$ adrenoceptor parameters (Day 2). Exposure of guinea pigs to high doses of inhaled acetylcholine for one week reduces $\beta$ adrenoceptor density in the lung membrane. ${ }^{49}$ However, affinity was unchanged and systemic $\beta$ adrenoceptors were not examined. ${ }^{49}$ Thus, even if - as seems unlikely - systemic $\beta$ adrenoceptors were affected by one methacholine challenge two days before sampling, changes in density rather than affinity would be expected, with the greatest changes occurring in subjects receiving the largest methacholine dose (young normals). Such an effect would blunt rather than produce or exaggerate the differences seen in our study.

The third and most important criticism of the suggestion that $\beta$ adrenoceptor ageing plays a major part in the pathogenesis of late onset asthma is quantitative rather than qualitative. Although acute intravenous $\beta$ blockade potentiates non-specific bronchial responsiveness in young non-asthmatic subjects, ${ }^{50}$ the potentiation is small (up to fourfold), whereas our elderly asthmatic patients possessed a degree of non-specific bronchial responsiveness 2000 times that of young normal subjects. However, this is likely to represent an oversimplification of the pathophysiology of chronic $\beta$ adrenoceptor dysfunction. The $\beta$ adrenergic system also modulates cholinergic neurotransmission at a prejunctional level with effects upon endogenous acetylcholine sensitivity up to 100 times more potent than its effects on response to exogenous cholinergic agents. ${ }^{51}$ Further, acute intravenous $\beta$ blockade would not produce immediate effects via other $\beta$ adrenergic-dependent mechanisms such as lung microvascular leakage, alveolar permeability, surfactant secretion, inhibition of mast cell mediator release and neutrophil lysozyme secretion, and stimulation of ciliated epithelial function..$^{52}$ Modulation of any of these systems could be expected to result in changes in bronchial responsiveness. Indeed, late asthmatic responses, which are paralleled by increases in non-specific bronchial responsiveness, ${ }^{53}$ are associatd with bronchial oedema and the release of prostaglandins, leukotrienes, and other mediators from mast cells and other sources. Furthermore, increases in epithelial permeability do enhance non-specific bron- 
chial responsiveness, ${ }^{54}$ and chronic asthma is associated with neutrophil accumulation in the airway and chronic oedema. ${ }^{55}$

We also showed the value of the methacholine challenge approach for the study of airway function in ageing. The methacholine challenge technique used for this study is well established. ${ }^{31}$ The use of FEF $_{50}$ as the ventilatory parameter was dictated by the need to obtain measurable bronchoconstriction in non-asthmatic subjects, and it is the small airway parameter which changes least with age. ${ }^{56}$ Expression of results as the simplified slope of the dose-response curve has been validated previously for $\mathrm{FEV}_{1} \cdot{ }^{37}$ The present study has shown its use with $\mathrm{FEF}_{50}$ to produce reproducible results (comparing favorably with more conventional indices using the same dosimeter in both young and elderly subjects ${ }^{3157}$, which discriminated well between subject groups.

Our overall conclusion is that age-associated reduction in $\beta$ adrenoceptor affinity for agonist (in the absence of any reduction in $\beta$ adrenoceptor density usually associated with juvenile onset asthma) plays a part in the aetiology of late onset asthma either by direct effects upon the $\beta$ adrenoceptor system in the airway or, more possibly, by modulation of the response of airway inflammatory cells, mediator release, or other indirect mechanisms. Although it is likely that late onset asthma is an age-related phenomenon, additional studies will be necessary to fully elucidate the mechanisms involved.

The authors thank Beth Musser and Bob Fritts for their invaluable technical help and advice.

Dr Connolly was supported by the British Geriatrics Society/ Nuffield Foundation Travelling Fellowship. Dr Crowley is the recipient of a Faculty Development Award in Clinical Pharmacology from the Pharmaceutical Manufacturers' Association Foundation. The project was supported in part by the Department of Veterans Affairs (Office of Research and Development, Medical Research Service) and by grants from the American Heart Association of Idaho and Glaxo Inc, USA.

1 Burr ML, Charles TJ, Roy K, Seaton A. Asthma in the elderly: an epidemiological survey. BMF 1979;1:1041-4.

2 Banerjee DK, Lee GS, Malik SK, Daly S. Underdiagnosi of asthma in the elderly. Br $\mathcal{F}$ Dis Chest 1987;81:23-9.

3 Cookson DU, Reed CE. A comparison of the effects of isoproterenol in the normal and asthmatic subject. $A m$ Rev Respir Dis 1963;88:636-43.

4 Parker CW, Smith JW. Alterations in cyclic adenosine monophosphate metabolism in human bronchial asthma. 1. Leukocyte responsiveness to beta-adrenergic agents. $\mathfrak{J}$ Clin Invest 1973;52:48-59.

5 Kariman K, Lefkowitz RJ. Decreased beta-adrenergic receptor binding in lymphocytes from patients with asthma. Lung 1980;158:41-51.

6 Brooks SM, McGowan K, Bernstein LI. Relationship between numbers of beta-adrenergic receptors in lymphocytes and disease severity in asthma. $\mathscr{f}$ Allergy Clin Immunol 1979;63:401-6.

7 Galant SP, Duriseti L, Underwood S, Allred S, Insel PA. Beta-adrenergic receptors of polymorphonuclear particulates in bronchial asthma. $\mathcal{f}$ Clin Invest 1980;65:577-85.

8 Sano Y, Watt G, Townley RG. Decreased mononuclear cell beta-adrenergic receptors in bronchial asthma: parallel studies of lymphocyte and granulocyte desensitization. $f$ Allergy Clin Immunol 1983;72:495-503.

9 Vestal RE, Wood AJ, Shand DG. Reduced beta-adrenoceptor sensitivity in the elderly. Clin Pharmacol Ther 1979;26:181-6.

10 Dillon N, Chung S, Kelly J, O'Malley K. Age and beta adrenoceptor-mediated function. Clin Pharmacol Ther adrenoceptor-m

11 Krall JF, Connelly M, Weisbart R, Tuck ML. Age-related elevation of plasma catecholamine concentration and revation of plasma catecholamine concentration and reduced responsiveness of lymphocyte a
$\Im$ Clin Endocrinol Metab 1981;52:863-7.

12 Abrass IB, Scarpace PJ. Catalytic unit of adenylate cyclase: reduced activity in aged-human lymphocytes. F Clin Endocrinol Metab 1982;55:1026-8.

13 Feldman RD, Limbird LE, Nadeau J, Robertson D, Wood AJJ. Alterations in leukocyte beta-receptor affinity with aging. A potential explanation for altered beta-adrenergic sensitivity in the elderly. $N$ Engl f Med 1984;310:815-9. 4 Townley RG, Ryo UY, Kolotkin BM, Kang B. Bronchial sensitivity to methacholine in current and former asthmatic and allergic rhinitis patients and control subjects. $f$ Allergy Clin Immunol 1975;56:429-42.

15 Cockcroft DW, Killian DN, Mellon JJA, Hargreave FE. Bronchial reactivity to inhaled histamine: a method and clinical survey. Clin Allergy 1977;7:235-43.

16 Juniper EF, Frith PA, Hargreave FE. Airway responsiveness to histamine and methacholine: relationship to minimum treatment to control symptoms of asthma. Thorax 1981;36:575-9.

17 Szentivanyi A. The beta-adrenergic theory of the atopic abnormality in bronchial asthma. $\mathcal{F}$ Allergy 1968;40:20332.

18 Malo J-L, Pineau L, Cartier A, Martin RR. Reference values and provocative concentrations of methacholine that cause $6 \%$ and $20 \%$ changes in forced expiratory volume in one second in a normal population. Am Rev Respir Dis 1983;128:8-11.

19 Hopp RJ, Bewtra A, Nair NM, Townley RG. The effect of age on methacholine response. $\mathcal{f}$ Allergy Clin Immuno 1985;76:609-13.

20 Lang DM, Hopp RJ, Bewtra AK, Nair NM, Watt GD Townley RG. Distribution of methacholine challenge responses in a selected adult population. $\mathcal{F}$ Allergy Clin Immunol 1987;79:533-40.

21 Woolcock AJ, Peat JK, Salome CM, Yan K, Anderson SD Schoeffel RE, et al. Prevalence of bronchial hyperresponsiveness and asthma in a rural adult population. Thorax 1987;42:361-8.

22 Burney PGJ, Britton JR, Chinn S, Tattersfield AE, Papacosta AO, Kelson MC, et al. Descriptive epidemiology of bronchial reactivity in an adult population: results from a community study. Thorax 1987;42:38-44.

23 Davis PB, Byard PJ. Relationships among reactivity, pupillary alpha-adrenergic and cholinergic responsiveness, and age. F Appl Physiol 1988;65:200-4.

24 Trigg CJ, Bennett JB, Tooley M, Sibbald B, D'Souza MF Davies RJ. A general practice based survey of bronchial hyperresponsiveness and its relation to symptoms, sex, age, atopy and smoking. Thorax 1990;45:866-72.

25 Sparrow D, O'Connor G, Colton T, Barry CL, Weiss ST The relationship of nonspecific bronchial responsiveness to the occurrence of respiratory symptoms and decreased to the occurrence of respiratory symptoms and decreased
levels of pulmonary function. The normative aging study. levels of pulmonary function. The normat

26 Cerveri I, Bruschi C, Zoia MC, Zanon P, Maccarini L, Grassi $M$, et al. Distribution of bronchial nonspecific reactivity in the general population. Chest 1988;93:26-30.

27 Davis PB, Byard PJ. Beta-adrenergic responses and airway reactivity in healthy adults. Mech Ageing Dev 1990;54:29 40.

28 Davis PB, Simpson DM, Paget GL, Turi V. Beta-adrenergic responses in drug-free subjects with asthma. $\mathcal{F}$ Allergy Clin Immunol 1986;77:871-9.

29 Connolly MJ, Crowley JJ, Nielson CP, Charan NE, Vestal RE. Relationship between nonspecific bronchial responsiveness to methacholine and peripheral mononuclear leukocyte beta-adrenergic receptor function in young leukocyte beta-adrenergic receptor function in young
drug-naive subjects. Am Rev Respir Dis 1992;146:592-7.

30 Nielson CP, Crowley JJ, Vestal, RE, Connolly MJ. Impaired beta-adrenoceptor function, increased lymphoImpaired beta-adrenoceptor function, increased lymphocyte respiratory burst, and bronchial hyperr
ness. $\mathcal{F}$ Clin Allergy Immunol 1992;90:825-32.

31 Connolly MJ, Avery AJ, Walters EH, Hendrick DJ. The relationship between bronchial responsiveness to methacholine and bronchial responsiveness to histamine in asthmatic subjects. Pulmon Pharmacol 1988;1:53-8.

32 Peuler JD, Johnson GA. Simultaneous single-isotope radioenzymatic assay of plasma norepinephrine, epinephrine and dopamine. Life Sci 1977;21:627-31.

33 Boyum A. Isolation of mononuclear cells and granulocytes from human blood. Scand $\mathcal{f}$ Clin Lab Invest 1967; 97(Suppl):77-89.

34 Bradford MM. A rapid and sensitive method for the quantitation of microgram quantities of protein utilizing the itation of microgram quantities of protein utilizing the
principle of protein dye binding. Anal Biochem 1976; principle of

35 Lundeen JE, Gordon JH. Computer analysis of binding data. In: O'Brian BO, ed. Receptor binding in drug research. New York: Marcel Dekker, 1985:31-49.

36 Marquardt DW. An algorithm for least squares estimation of non-linear parameters. $\mathcal{F}$ Soc Appl Math 1963;11:43144.

37 O'Connor G, Sparrow D, Taylor D, Segal M, Weiss S. Analysis of dose-response curves to methacholine. An approach suitable for population studies. Am Rev Respir Dis 1987;136:1412-7.

38 Bland JM, Altman DG. Statistical methods for assessing agreement between two methods of clinical measurement. agreement between two
Lancet $1986 ; \mathrm{i}: 307-10$.

39 Abrass IB, Scarpace PJ. Human lymphocyte beta-adrenergic receptors are unaltered with age. $\mathcal{f}$ Gerontol gic receptors are
$1981 ; 36: 298-301$.

40 Landmann R, Bittiger H, Buhler FR. High affinity betaadrenergic receptors in mononuclear leukocytes: similar adrenergic receptors in mononuclear leukocytes: similar density in young
$1981 ; 29: 1761-71$.

41 Doyle V, O'Malley K, Kelly JG. Human lymphocyte betaadrenoceptor density in relation to age and hypertension. f Cardiovasc Pharmacol 1982;4:738-40.

42 Kent RS, De Lean A, Lefkowitz RJ. A quantitative analysis of beta-adrenergic receptor interactions: resolution of 
high and low affinity states of the receptor by computer modeling of ligand binding data. Mol Pharmacol 1980;17:14-23.

43 Feldman RD, Limbird LE, Nadeau J, FitzGerald GA, Robertson D, Wood AJJ. Dynamic regulation of leukocyte beta adrenergic receptor-agonist interactions by physiological changes in circulating catecholamines. $\mathcal{f}$ Clin Invest 1983;72:164-70

44 Doyle VM, O'Malley K, Kelly JG. Lymphocyte cyclic AMP production in the elderly: the effects of prostaglandin $\mathrm{E}_{1}$. Br f Clin Pharmacol 1981;12:597-8.

45 Ziegler MG, Lake CR, Kopkin IJ. Plasma noradrenaline increases with age. Nature 1976;261:333-5.

46 Bakke PS, Baste V, Gulsvik A. Bronchial responsiveness in a Norwegian community. Am Rev Respir Dir 1991; a Norwegian

47 Sparrow D, O'Connor GT, Rosner B, Segal MR, Weiss $S T$. The influence of age and level of pulmonary function on nonspecific airway responsiveness. The Normative Aging Study. Am Rev Respir Dis 1991;143:978-82.

48 Hauck RW, Bohm , Gegenbach S, Sunder-Plassmann Fruhmann G, Erdmann E. Beta, -adrenoceptors in human lung and peripheral mononuclear leukocytes of untreated and terbutaline-treated patients. Chest 1990;98:376-81.

49 Mita $\mathrm{H}$, Yasuo Y, Shida T. Changes of beta-adrenergic receptor number and catecholamine-sensitive adenylate cyclase in guinea-pig lung after inhalation of histamine aerosol. Int Arch Allergy Appl Immunol 1983;72:373-6.
50 Orehek J, Gayrard P, Grimaud C, Charpin J. Effect of beta adrenergic blockade on bronchial sensitivity to inhaled acetylcholine in normal subjects. $\mathcal{f}$ Allergy Clin Immunol 1975;55:164-9.

51 Rhoden KJ, Meldrum LA, Barnes PJ. Inhibition of cholinergic neurotransmission in human airways by beta-adrenoceptors. F Appl Physiol 1988;65:700-5.

52 Barnes PJ. Beta-adrenoceptors in lung tissue. In: Morley J, ed. Perspectives in asthma. 2.Beta-adrenoceptors in asthma. London: Academic Press, 1984:67-90.

53 Cockcroft DW, Ruffin RE, Dolovich J, Hargreave FE. Allergen induced increase in non-allergic bronchial reactivity. Clin Allergy 1977;7:503-13.

54 Pare $P$. Bronchial reactivity in animals and its relationship to bronchial permeability. In: Hargreave FE, ed. Airway reactivity: mechanisms and clinical relevance. Mississauga, Ontario: Astra Publications, 1980:49-53.

55 Kay AB. Basic mechanisms in allergic asthma. Eur $\mathcal{f}$ Respir Dis 1982:(Suppl);122:9-16.

56 Knudson RL, Dumont FC, Kennedy TC, Knudson DE. Effect of aging alone on the mechanical properties of the normal human lung. F Appl Physiol 1977;43:1054-62.

57 Connolly MJ, Kelly C, Walters EH, Hendrick DJ. An assessment of methacholine inhalation tests in elderly asthmatics. Age Ageing 1988;17:123-8.

58 Morris JF. Spirometry in the evaluation of pulmonary function, medical progress. West 7 Med 1976;125:110-8. 